OPEN ACCESS

Edited by:

John Moore,

Stellenbosch University,

South Africa

Reviewed by:

Tsanko Savov Gechev,

Plovdiv University "Paisii Hilendarski",

Bulgaria

Klaus Herburger,

University of Copenhagen,

Denmark

${ }^{*}$ Correspondence:

Dorothea Bartels

dbartels@uni-bonn.de

Specialty section: This article was submitted to

Plant Abiotic Stress,

a section of the journal

Frontiers in Plant Science

Received: 18 September 2019 Accepted: 02 December 2019

Published: 21 January 2020

Citation:

Chen P, Jung NU, Giarola V and Bartels D (2020) The Dynamic Responses of Cell Walls in Resurrection Plants During Dehydration and Rehydration. Front. Plant Sci. 10:1698. doi: 10.3389/fpls.2019.01698

\section{The Dynamic Responses of Cell Walls in Resurrection Plants During Dehydration and Rehydration}

\author{
Peilei Chen, Niklas Udo Jung, Valentino Giarola and Dorothea Bartels* \\ Faculty of Natural Sciences, Institute of Molecular Physiology and Biotechnology of Plants (IMBIO), University of Bonn, \\ Bonn, Germany
}

Plant cell walls define the shape of the cells and provide mechanical support. They function as osmoregulators by controlling the transport of molecules between cells and provide transport pathways within the plant. These diverse functions require a welldefined and flexible organization of cell wall components, i.e., water, polysaccharides, proteins, and other diverse substances. Cell walls of desiccation tolerant resurrection plants withstand extreme mechanical stress during complete dehydration and rehydration. Adaptation to the changing water status of the plant plays a crucial role during this process. This review summarizes the compositional and structural variations, signal transduction and changes of gene expression which occur in cell walls of resurrection plants during dehydration and rehydration.

Keywords: cell wall composition, cell wall signaling, transcriptomes, resurrection plants, dehydration, rehydration

\section{INTRODUCTION}

Plants as sessile organisms cope with environmental challenges by adopting a wide spectrum of strategies (Bartels and Salamini, 2001). Drought, a pervasive stress, causes water deficit (Bray, 1997) and may even lead to desiccation, a condition where only the bound water is left in the plant cells (Ramanjulu and Bartels, 2002; Zhang and Bartels, 2018). Although seeds of higher plants withstand desiccation (Bewley, 1979), vegetative tissues of most plants do not tolerate a water content which is below 60-30\% (Challabathula and Bartels, 2013; Zhang and Bartels, 2018). However, some bryophytes, ferns, and a few angiosperms can survive in an extremely arid environment (Alpert, 2000). The desiccation tolerant plants, termed resurrection plants, can equilibrate their vegetative tissues with nearly 0\% relative humidity (Gaff, 1971), stay in a dehydrated, quiescent stage for months, and resurrect once water is available again. Water loss leads to plasmolysis and subsequently causes mechanical stress (Moore et al., 2006; Plancot et al., 2019). Desiccation tolerant tissues can avoid or resist detrimental effects of this stress through increased vacuolation and/or cell wall folding (Figure 1) (Webb and Arnott, 1982; Moore et al., 2006; Farrant et al., 2007) which requires structural flexibility as well as physiological and molecular responses in the cell wall. In this review, we will focus on the changes in polysaccharide

Abbreviations: OGAs, Oligosaccharides; WAKs, Wall-associated protein kinases; ROS, Reactive oxygen species; RLKs, Receptor-like kinases; ABA, abscisic acid; GRP, Glycine-rich protein; AGPs, Arabinogalactan proteins; XTHs, Xyloglucan endotransglucosylases/hydrolases. 
composition, cell wall signaling, and transcriptional changes, which are linked to reversible cell wall folding in resurrection plants (Figure 1).

\section{DYNAMIC PECTIN CHANGES IN RESURRECTION PLANTS UPON DESICCATION/REHYDRATION}

The cell walls encapsulate plant cells and provide mechanical strength. They define the morphology, and are implicated in plant growth and responses to environmental stresses (Pilling and Höfte, 2003; Hamann, 2014). Important building blocks of cell walls are cellulose, callose, pectin, and hemicelluloses. Pectin is the most abundant component and accounts for up to $50 \%$ (w/w) of the cell wall in Arabidopsis thaliana (Zablackis et al., 1995). Cellulose and callose are linear homopolysaccharides and are composed of $\beta$-(1,4)- and $\beta$-(1,3)-linked glucose residues, respectively. Cellulose microfibrils are interconnected by hemicelluloses and pectin and form rigid structures which build up the mechanical scaffold of the cell wall (Nishiyama, 2009; Wang et al., 2012). Pectin is a heterogenous matrix of homogalacturonan, rhamnogalacturonan-I, and rhamnogalacturonan-II. Homogalacturonan is typically most abundant and accounts for about $65 \%$ of pectin. Rhamnogalacturonan-I accounts for $20-35 \%$ and rhamnogalacturonan-II is a minor component (Mohnen, 2008). $\alpha$-(1,4)-Linked D-galacturonic acid is a building block of homogalacturonan, where it is arranged in linear chains. Galacturonic acid is also the building block of rhamnogalacturonan-II and, together with rhamnose, the backbone of rhamnogalacturonan-I. Rhamnogalacturonan-I and rhamnogalacturonan-II are more complex than homogalacturonan, because galacturonic acid and rhamnose are substituted by other sugar residues. The biosynthesis of pectin has been reviewed recently (Harholt et al., 2010; Lampugnani et al., 2018) and will not be described further. Xyloglucan and xylan are the most abundant hemicelluloses in dicot cell walls and crosslink cellulose fibrils (Park and Cosgrove, 2015; Simmons et al., 2016). Xyloglucan has a $\beta$ - $(1,4)$-linked glucose backbone with side chains which contain xylose, galactose (possibly acetylated), fucose, and arabinose. Xylan is made of $\beta$ - $(1,4)$-linked xylose residues with side chains of $\alpha$-arabinofuranose and $\alpha$-galacturonic acid. Modifications such as transglucosylation, acetylation, or methylesterification and cross-linking of the different cell wall components play a major role in modifying the mechanical properties of plant cell walls (O'Neill et al., 2001; Ryden et al., 2003; Caffall and Mohnen, 2009; Caffall et al., 2009; Park and Cosgrove, 2015). Analyzing the behavior of the polysaccharide matrix in response to stress is essential to understand the flexibility of cell walls. Upon desiccation, the vacuole shrinks, and the cell contents are drawn inwards, which results in more tension between the plasmalemma and the cell wall (Levitt and Levitt, 1987). Callose synthesis is induced in response to different stresses and it functions as a local cell wall stabilizer (Nielsen et al., 2012; De Storme and Geelen, 2014). Upon desiccation most resurrection plants undergo extensive folding of the cell wall, a process which is quickly reversed during rehydration (Phillips et al., 2008; Jung et al., 2019). Controlled cell wall folding prevents tearing of the plasmalemma from the cell wall, which is essential to maintain cell integrity (Thomson and Platt, 1997; Farrant and Sherwin, 1998; Vicré et al., 1999; Farrant, 2000; Vicré et al., 2004b). The degree of folding depends on the leaf morphology and the leaf area e.g. the leaves of the desiccation tolerant grass Oropetium thomaeum (VanBuren et al., 2017) are narrow and the degree of folding is less than in Craterostigma plantagineum. Cells of desiccated leaves show the most extensive folding after dehydration compared to cells of roots or stems.

In resurrection plants, changes in homogalacturonan, rhamnogalacturonan-I, rhamnogalacturonan-II, and hemicelluloses were investigated in leaves of C. plantagineum, $C$. wilmsii, and Lindernia brevidens during dehydration and rehydration to understand cell wall plasticity (Vicré et al., 1999; Jung et al., 2019). Higher levels of de-methylesterified homogalacturonan were found upon desiccation which was reversed after rehydration. Homogalacturonan is synthesized in the methylesterified form and subsequently de-methylesterified in the cell wall, which suggests de novo synthesis of homogalacturonan during rehydration (Zhang and Staehelin, 1992; Staehelin and Moore, 1995; Sterling et al., 2001). A high proportion of de-methylesterified homogalacturonan upon
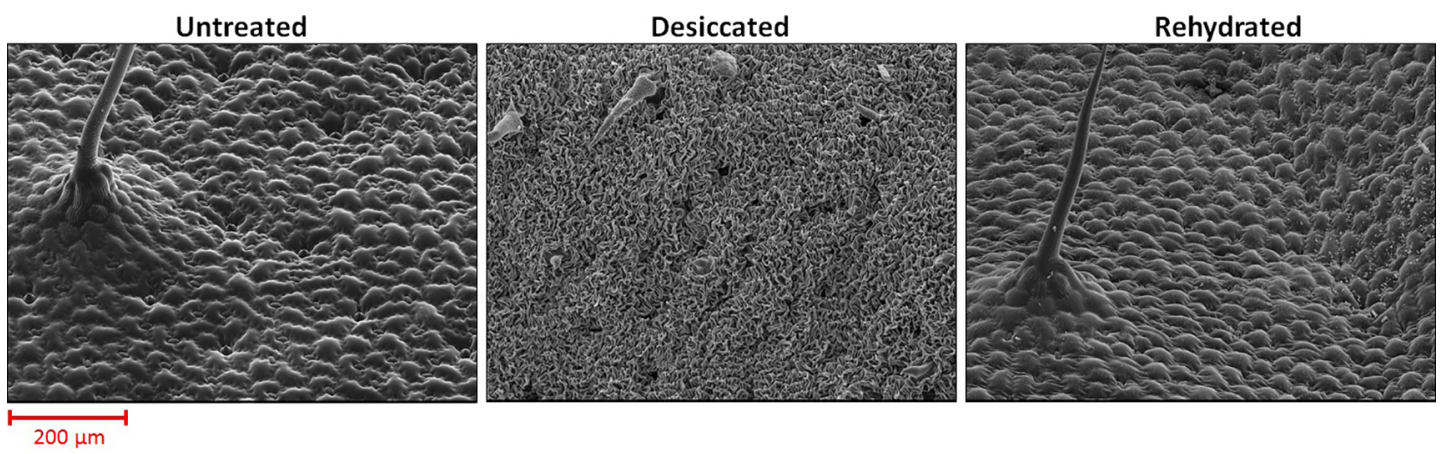

FIGURE 1 | Surface images of Craterostigma plantagineum leaves taken with a scanning electron microscope. Micrographs were taken from untreated (RWC = 100\%), desiccated $(\mathrm{RWC}=2 \%)$ and rehydrated $(\mathrm{RWC}=90 \%)$ leaves. 
desiccation in combination with calcium (Vicré et al., 1999) leads to the formation of the so-called "egg-box" structures (Figure 2) (Grant et al., 1973; Jarvis, 1984; Moore et al., 1986; Lloyd, 1991) which are proposed to strengthen the cell wall (Vicré et al., 1999; Jung et al., 2019). Highly de-methylesterified homogalacturonan provides additional binding sites for pectin binding proteins which might be important to sense the cell wall hydration status (Giarola et al., 2016; Jung et al., 2019). A role of homogalacturonan in desiccation tolerance is supported by a report that correlates accumulation of homogalacturonan with desiccation resistance in the green algae Zygnema sp. (Herburger et al., 2019). Changes in rhamnogalacturonan-I, rhamnogalacturonan-II, and the hemicelluloses may reinforce the cell wall upon desiccation in resurrection plants. In $C$. wilmsii and $C$. plantagineum the xyloglucan levels increased upon desiccation (Vicré et al., 1999; Jung et al., 2019). More xyloglucan points to an increase of interconnected cellulose fibrils and thus enhances cell wall rigidity (Moore et al., 1986; Fry, 1989; Park and Cosgrove,
2015). Xylan, another cellulose-linking cell wall component, is also increased upon desiccation but motile and flexible cell wall components like $\beta$-1,4-galactan and $\alpha$-1,5-arabinan do not change (Jung et al., 2019). In C. plantagineum, dehydration leads to changes in rhamnogalacturonan-II (Jung et al., 2019). In the studied resurrection plants, the changes in the pectin composition lead to a more rigid cell wall upon dehydration (Vicré et al., 1999; Jung et al., 2019). Crosslinking of homogalacturonan via $\mathrm{Ca}^{2+}$ and rhamnogalacturonan-II via borate strengthens the cell wall (Kobayashi et al., 1996).

\section{CELL WALL SIGNALING IN RESURRECTION PLANTS DURING DEHYDRATION}

The plant cell wall has a complex signaling system which monitors cell wall integrity by detecting chemical and physical

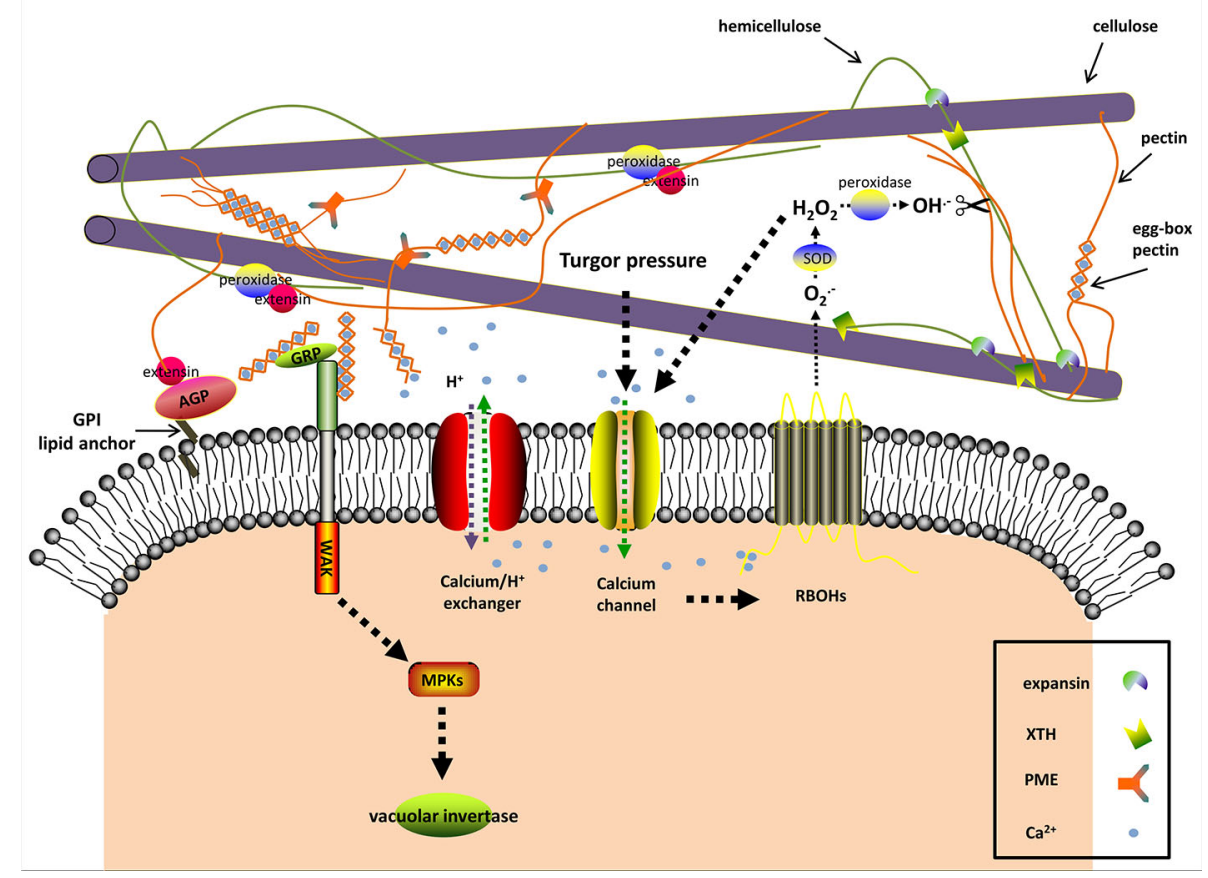

FIGURE 2 | The predicted interactions among apoplastic proteins and signaling molecules in resurrection plants during dehydration. Dehydration induces turgor pressure changes, which are sensed by mechanosensitive (MS) calcium channels As a consequence [Ca $\left.{ }^{2+}\right]_{\text {cyt }}$ levels rise. The plasma membrane-localized $\mathrm{NADPH}$ oxidases (respiratory burst oxidase homologs, $\mathrm{RBOHs}$ ) are activated through binding $\left[\mathrm{Ca}^{2+}\right]_{\mathrm{cyt}}$ and produce $\mathrm{O}_{2}{ }^{-}$, a substrate of the cell wall superoxide dismutase (SOD). The apoplastic $\mathrm{H}_{2} \mathrm{O}_{2}$ as the product of $\mathrm{SOD}$ also leads to $\mathrm{Ca}^{2+}$ influx. Cell wall peroxidases produce hydroxyl radicals $\left(\mathrm{OH}^{-}\right)$with apoplastic $\mathrm{H}_{2} \mathrm{O}_{2}$ as substrate. The reactive $\mathrm{OH}^{-}$is able to rupture glycosidic bonds and leads to cell wall loosening. In addition to $\mathrm{OH}^{-}$, expansin and xyloglucan endotransglucosylase/ hydrolase (XTH) may contribute to loosening the cell wall by disrupting the interaction between hemicellulose and cellulose during the early stages of dehydration and rehydration. Cell wall peroxidases facilitate wall stiffness by reinforcing the cross-linking of extensin with cell wall polysaccharides. Excessive [Ca $\left.{ }^{2+}\right]_{\text {cyt }}$ is toxic and thus $\left[\mathrm{Ca}^{2+}\right]_{\mathrm{cyt}}$ is transported to the extracellular space by $\mathrm{Ca}^{2+}$ efflux systems ( $\mathrm{Ca}^{2+}$ exchangers are shown). The alkalization in the apoplast affects the activity of many cell wall proteins, one of which is pectinmethylesterase (PME). PME exerts its demethylesterifying role on pectin in alkalized apoplast and generates negatively charged pectins, which form the egg-box pectin gelatin with apoplastic $\mathrm{Ca}^{2+}$ and increase wall stiffness. Wall-associated kinase (WAK) forms a complex with the glycine-rich protein (GRP) and can detect the egg-box pectin. This then in turn activates the vacuolar invertase activity. The classic (glycosylphosphatidyl inositol) GPI-anchored cell wall arabinogalactan proteins (AGPS) are involved in signal transduction between the intracellular and extracellular compartments and act as plasticizers in resurrection plants against desiccation. The signaling pathway and the interactions in the apoplast are hypothesized according to the available literatures and the current research on cell walls of resurrection plants. 
modifications of the cell wall polymers and then transduces this information into the cell to trigger appropriate responses (Seifert and Blaukopf, 2010; Voxeur and Höfte, 2016). Signaling pathways resemble yeast signaling mechanisms and can be activated by various stimuli including drought stress (Hamann, 2014). Different molecules, including reactive oxygen species (ROS) and hormones, are integrated in cell wall-mediated signaling cascades (Miller et al., 2010; Choudhury et al., 2017; Novaković et al., 2018). An overview of the different physical and chemical signals and pathways is provided in the following paragraphs.

\section{Turgor Pressure and Turgor Sensors}

Turgor pressure is the result of the osmotic pressure in the symplast and the mechanical strength of the cell wall (Cleland, 1971; Lewicki, 1998; Ringli, 2010). Altered turgor pressure can be perceived as physical signal by cell wall sensors such as ion channels, leading to the flow of $\mathrm{Ca}^{2+}$ between intra- and extracellular spaces according to the plasma membrane tension (Seifert and Blaukopf, 2010; Hamann, 2014; Hamilton et al., 2015) (Figure 2). Dehydration lowers the turgor pressure, thus stopping cell expansion and growth (Tardieu et al., 2014). The resurrection plant Myrothamnus flabellifolia maintains cell turgor and copes with the mechanical stress by increasing cell wall elasticity with plasticizers, i.e., arabinose-containing polymers (Moore et al., 2013). These polymers might act as "mechanosensors" as well (Moore et al., 2006; Moore et al., 2008; Le Gall et al., 2015).

Turgor pressure changes, as a result of dehydration, are perceived as mechanical signals by a specialized plasma membrane localized-mechanosensory gauge, termed mechanosensitive or stretch-activated ion channel (Figure 2) (Seifert and Blaukopf, 2010; Hamilton et al., 2015). The pore-forming mechano-sensitive ion channels control ion passage via sensing the membrane tension and thus trigger the downstream signaling. In this way the change of mechanical force is sensed at the membrane-wall interface and acts as cell wall integrity sensor (Seifert and Blaukopf, 2010; Wolf et al., 2012; Basu and Haswell, 2017). In plants, three mechanosensitive channel families have been characterized, namely MscS-like channels, two-pore domain $\mathrm{K}^{+}$channels, and Mid1-complementing activity channels (Hamilton et al., 2015; Basu and Haswell, 2017). The non-selective mechanosensitive-like channels are classified into three groups, among which the plastidlocalized group II MscS-like 2 and MscS-like 3 are correlated with plastid osmotic stress and abscisic acid (ABA) induction. Overexpression of plasma membrane-localized group III MscSlike 10 can result in $\mathrm{H}_{2} \mathrm{O}_{2}$-associated cell death (Veley et al., 2014; Hamilton et al., 2015). The Mid1-complementing activity channels $\left(\mathrm{Ca}^{2+}\right.$-permeable mechanosensitive channels) are tightly associated with $\mathrm{Ca}^{2+}$ influx and involved in regulating $\mathrm{Ca}^{2+}$ homoeostasis (Hamilton et al., 2015). The transcriptome analysis of the angiosperm resurrection plant C. plantagineum and the desiccation-tolerant lichen Cladonia rangiferina revealed elevated expression of genes encoding pore calcium channels and other non-defined ion channels upon dehydration (Rodriguez et al., 2010; Junttila et al., 2013; Giarola et al., 2015).

\section{Pectin-Derived Oligosaccharides}

Many studies identified breakdown products of pectin as signaling molecules (Bidhendi and Geitmann, 2016; Cosgrove, 2016; Voxeur and Höfte, 2016). Pectin-derived oligosaccharides (OGAs) were first discovered in plant pathogen studies and belong to a class of elicitors, leading to damage-associated molecular patterns (DAMPs) or pathogenassociated molecular patterns (PAMPs), which are related to wounding or diseases (De Lorenzo et al., 2018; Nürnberger and Kemmerling, 2018). The cell wall surveillance system is able to distinguish the degree of polymerization and conformation of OGAs and to trigger different responses, accordingly (Cabrera et al., 2008; Osorio et al., 2008; Cabrera et al., 2010). In A. thaliana de-methylesterified pectin stretches bind to calcium and form so-called "egg-box" structures which are recognized by cell wall-associated protein kinases (WAKs) (Decreux and Messiaen, 2005). Dehydration leads to a higher level of de-methylesterified pectin and an increase in the concentration of calcium in the cell wall of the resurrection species Craterostigma (Vicré et al., 1999; Vicré et al., 2004a; Jung et al., 2019), which is the basis for the "egg-box" formation and the pectin-WAK association. These results support a role for OGAs as signal molecules in resurrection plants during water deficit (Figure 2). The xyloglucan-derived OGAs also regulate cell wall expansion (Pilling and Höfte, 2003; Seifert and Blaukopf, 2010). Fry et al. (1990) observed the modulating effects of xyloglucan-derived OGAs in plant growth. Takeda et al. (2002) proposed the involvement of the xyloglucan metabolism in cell elongation. During dehydration the structure and distribution of xyloglucan are significantly altered in resurrection plants (Vicré et al., 1999; Vicré et al., 2004a; Vicré et al., 2004b). Therefore, it is tempting to speculate that xyloglucan is involved in defense responses under dehydration, when other intrinsic defense systems are shut-down.

\section{Calcium}

Calcium participates in multiple biological processes and has different functions in the cell wall. Besides a structural role in forming "egg-box" structures, calcium can move in and out of the cell and functions as second messenger (Parre and Geitmann, 2005; Bose et al., 2011; Kurusu et al., 2013). The majority of $\mathrm{Ca}^{2+}$ is localized in the apoplast and vacuole (Medvedev, 2005). In the apoplast, the excess of free $\mathrm{Ca}^{2+}$ is sequestered via the formation of "egg-box" structures (Voxeur and Höfte, 2016), which also serves as reservoir for cytosolic calcium $\left(\left[\mathrm{Ca}^{2+}\right]_{\text {cyt }}\right)$. Transient $\left[\mathrm{Ca}^{2+}\right]_{c y t}$ elevation is a ubiquitous signal when plant cells encounter abiotic or biotic stress (Bose et al., 2011), which can be induced by OGAs (Moscatiello et al., 2006), and ascorbate (Makavitskaya et al., 2018). $\left[\mathrm{Ca}^{2+}\right]_{\text {cyt }}$ elevation activates ROS production, and vice versa. ROS can also cause $\mathrm{Ca}^{2+}$ influx thus facilitating signal propagation (Seifert and Blaukopf, 2010; Kurusu et al., 2013) (Figure 2). Because $\mathrm{Ca}^{2+}$ reacts with proteins and other substances in the cytoplasm, high concentrations of $\left[\mathrm{Ca}^{2+}\right]_{c y t}$ are detrimental. Therefore it is necessary to maintain the basal $\left[\mathrm{Ca}^{2+}\right]_{\mathrm{cyt}}$ levels with the help of cytosolic buffering systems and $\mathrm{Ca}^{2+}$ efflux systems 
$\left(\mathrm{Ca}^{2+}\right.$-ATPases and $\mathrm{Ca}^{2+}$ exchangers) (Bose et al., 2011) (Figure 2). Repetitive $\mathrm{Ca}^{2+}$ influx and efflux give rise to cytosolic calcium oscillations, which vary in magnitude, frequency, and shape and are related to the severity and type of stress (Bose et al., 2011). Long term drought in soybean induced large $\mathrm{Ca}^{2+}$ efflux from mesophyll cells, accompanied by large $\mathrm{K}^{+}$efflux and $\mathrm{H}^{+}$influx, which may prime the $\mathrm{ABA}$ signal transduction in guard cells and finally lead to stomata closure (Mak et al., 2014). Similar to soybean, the apoplastic $\mathrm{Ca}^{2+}$ was also increased in the resurrection plant $C$. wilmsii upon dehydration, but with no significant change of $\mathrm{K}^{+}$in the cell wall (Vicré et al., 2004a), which suggests that the resurrection plants may have a specific $\mathrm{Ca}^{2+}$ signaling mechanism. Mihailova et al. (2018) speculated that the accumulation of $\mathrm{Ca}^{2+}$ in the cell wall of $C$. wilmsii resulted from electrolyte leakage. This explanation may overlook the fact that neither the apoplastic $\mathrm{K}^{+}$nor the phosphate significantly increased. The apoplastic $\mathrm{Ca}^{2+}$ in C. wilmsii was quantified using secondary ion mass spectrometry technology. However, the studies of $\mathrm{Ca}^{2+}$ signature require more real-time data and $\mathrm{Ca}^{2+}$ levels should be determined using microelectrode ion flux measurement and dynamic calcium imaging (Krebs et al., 2012).

\section{Protons}

The proton influx and efflux across the plasma membrane can lead to apoplastic alkalization or acidification, which dictates the activities of $\mathrm{pH}$-dependent cell wall modifying enzymes and finally affects cell wall structures. Water deficit, similar to other stresses such as salinity or pathogen infection tends to decrease proton concentrations in the apoplast (Geilfus, 2017). Increased apoplastic $\mathrm{pH}$ inhibits expansin activity and activates pectinmethylesterases, which together with elevated $\left[\mathrm{Ca}^{2+}\right]_{\text {apo }}$ eventually strengthen the cell wall (Wolf et al., 2012) (Figure 2). The cell wall $\mathrm{pH}$ also varies spatially with a lower $\mathrm{pH}$ in the growing tip, thereby promoting cell wall loosening in apical tips (Moore et al., 2008; Mangano et al., 2018). Systemic apoplastic alkalinization is considered as a stress signal stimulating $\mathrm{ABA}$ accumulation in guard cells and stomatal closure during dehydration (Geilfus, 2017; Karuppanapandian et al., 2017). Therefore it is essential to consider the effect of $\mathrm{pH}$ on the activity of cell wall modifying enzymes in more detail.

\section{ROS and ROS-Producing Enzymes}

Reactive oxygen species (ROS), including hydrogen peroxide $\left(\mathrm{H}_{2} \mathrm{O}_{2}\right)$, hydroxyl radical $\left(\mathrm{OH}^{-}\right)$, superoxide anion $\left(\mathrm{O}_{2}^{-}\right)$, and nitric oxide (NO) are a group of reactive molecules with partially reduced or active forms of oxygen (Choi et al., 2017). Historically ROS were only considered to be toxic for cell metabolism, but now it is widely accepted that ROS also act as important transmitters for both intra- and intercellular signaling (Hamann et al., 2009; Choudhury et al., 2017; Mittler, 2017). The apoplastic ROS trigger multiple downstream responses which demands a precise signal perception and transduction from the apoplast to the nucleus (Wrzaczek et al., 2013; Kangasjärvi and Kangasjärvi, 2014). The ROS signaling in the extracellular compartment has not been well deciphered. The predicted ROS sensing and transduction involve plasma membrane receptor-like kinases (RLKs), ion channels, aquaporins, redox balancing substances, plasma membrane lipid oxidation, and modification of cysteine residues in relevant proteins (Dynowski et al., 2008; Spoel and Loake, 2011; Kangasjärvi and Kangasjärvi, 2014). In resurrection plants not many studies on apoplastic ROS signaling exist. Based on observations of Ramonda nathaliae Jovanović et al. (2011) proposed that controlled production of ROS is a vital part in sensing dehydration and inducing multiple responses.

In plants, a considerable amount of ROS is generated intracellularly due to photosynthesis, mitochondrial respiration, photorespiration, and other processes caused by diverse stresses (Kimura et al., 2017; Mittler, 2017). In the extracellular space, the plasma membrane-localized NADPH oxidases (respiratory burst oxidase homologs) and cell wall peroxidases are the main sources for ROS production (Suzuki et al., 2011; O’Brien et al., 2012; Choudhury et al., 2017; Kimura et al., 2017). The respiratory burst oxidase homologs are activated via the influx of apoplastic $\mathrm{Ca}^{2+}$, internal $\mathrm{Ca}^{2+}$ binding, and phosphorylation (Baxter et al., 2014) (Figure 2). Under stress respiratory burst oxidase homologs are not only ROS producers, but also transmit ROS waves from one cell to neighboring cells (Choi et al., 2017). The apoplastic $\mathrm{H}_{2} \mathrm{O}_{2}$ is derived from spontaneous chemical reactions or superoxide dismutase-mediated mutation of superoxide which is generated from respiratory burst oxidase homologs (Figure 2) (Baxter et al., 2014), xanthine dehydrogenase (Ma et al., 2016), and oxalate oxidase (Voothuluru and Sharp, 2013). The comparative genome analysis of the desiccation tolerant lycophyte Selaginella tamariscina and the desiccation-sensitive Selaginella moellendorffii showed that the number of ROS-producing genes such as respiratory burst oxidase homologues and oxalate oxidase genes are much lower in the genome of the desiccation tolerant S. tamariscina compared to S. moellendorffii (Xu et al., 2018). This indicates that $S$. tamariscina may produce less apoplastic ROS and thus alleviates stress to cell membranes during water deficit. Choudhury et al. (2017) suggested that the ROS detoxification mechanisms within the cell walls are less effective than intracellular mechanisms, because they rely on low levels of ascorbate and glutathione, CuZn-superoxide dismutases, or cell wall peroxidases. This causes the accumulation of extracellular ROS which facilitates rapid systemic auto-propagating ROS waves (Choi et al., 2017; Choudhury et al., 2017). Despite being known as ROSscavengers peroxidases also produce hydroxyl radicals from $\mathrm{H}_{2} \mathrm{O}_{2}$ which are capable of cleaving cell wall polysaccharides (Figure 2) (Fry, 1998; Passardi et al., 2004). Peroxidases in cell walls interact with polysaccharides and extensins, and supply phenoxy radicals for cell wall lignification and suberization (Figure 2) (Passardi et al., 2004; Tenhaken, 2015). Hence, peroxidases have dual functions: they contribute to wall loosening by releasing hydroxyl radicals and they boost wall stiffness by solidifying the extensin cross-linkages and supporting cell wall lignification and suberization (Novaković et al., 2018). Reinforcing the cell wall is an effective way to increase 
mechanical strength and to counteract increasing osmotic stress in response to dehydration. However, cell wall loosening is necessary for cell growth. In some resurrection plants the activities of peroxidases are highly increased upon rehydration, but do not change during dehydration (Sherwin and Farrant, 1998; Rodriguez et al., 2010; Deeba et al., 2016; Yobi et al., 2017). The limited activity of peroxidases may facilitate cell wall loosening and help reversible cell wall folding. In other resurrection plants, such as $X$. viscosa, peroxidases are upregulated during dehydration but down-regulated upon rehydration, which is a prerequisite for cell wall stiffness under drought (Sherwin and Farrant, 1998; Ingle et al., 2007). Low-level substrates or decreased activity of peroxidases tend to generate hydroxyl radicals which lead to cell wall loosening and on the contrary high amounts of peroxidases, substrates, and ROS facilitate cell wall stiffness (Tenhaken, 2015).

\section{Receptor-Like Protein Kinases}

The decoding of environmental cues and detection of cell wall perturbation under dehydration require special sensing mechanisms. Components of these sensors are members of RLK sub-families. RLKs generally consist of an extracellular domain, presiding over the perception of signals, a transmembrane region, and an intracellular kinase domain which triggers the downstream intracellular signaling (Ringli, 2010; Tenhaken, 2015; Novaković et al., 2018). Cell wall RLKs have been demonstrated to exert pivotal roles in plant development, growth and responses under various stresses, among which the well-characterized Catharanthus roseus protein kinase1-like receptor kinases (CrRLKs) and cell wallassociated protein kinases (WAKs) are candidates for cell wall integrity sensors (Novaković et al., 2018). In A. thaliana, there are 17 members of CrRLK (Lindner et al., 2012). Their involvement in $\mathrm{Ca}^{2+}$ signaling and ROS production during pollen tube growth, root hair elongation, or stress responses have been confirmed particularly for THESEUS1, FERONIA, and ANXUR (Hématy et al., 2007; Cheung and Wu, 2011; Denness et al., 2011; Boisson-Dernier et al., 2013; Feng et al., 2018). The FERONIA triggered-signaling is additionally regulated by a group of small peptides, RALFs (rapid alkalinization factors), which bind to FERONIA and also regulate a $\mathrm{H}^{+}$-ATPase and thus adjust the extracellular $\mathrm{pH}$ which subsequently determines activities of cell wallremodeling enzymes (Murphy and De Smet, 2014). In analogy to FERONIA, the C. plantagineum WAK1 (CpWAK1) is a binding partner for the cell wall protein CpGRP1 (C. plantagineum glycine-rich protein1) (Giarola et al., 2016), and the A. thaliana WAK1 showed binding to both the AtGRP-3 protein and OGAs (Figure 2) (Decreux and Messiaen, 2005). WAKs are connected with turgor pressure as it was demonstrated that Arabidopsis plants silenced for WAKs had impaired cell expansion and reduced expression and activity of the vacuolar invertase (Kohorn et al., 2006). CpGRP1 and CpWAK1 accumulate in opposite directions upon dehydration and rehydration with more CpGRP1 and less CpWAK1 in desiccated samples compared to hydrated or rehydrated samples (Giarola et al., 2016). It was recently demonstrated that also CpGRP1 interacts with pectin and that the interaction is dependent on the homogalacturonan methylesterification status of pectin (Jung et al., 2019). The CpGRP1 protein binds stronger to homogalacturonan isolated from desiccated leaves than to homogalacturonan from hydrated leaves, where the degree of methylesterification is lower than in hydrated leaves. The data imply that both CpWAK1 and CpGRP1, or the CpWAK1-CpGRP1 complex participate in sensing changes in the cell wall organization and might trigger cell wall remodeling processes during dehydration (Figure 2).

\section{Hydroxyproline-Rich Proteins}

Hydroxyproline-rich proteins are composed of highly Oglycosylated proteoglycans and exist in two forms in plants, one of which is insoluble and localized in the apoplast (Deepak et al., 2010; Shivaraj et al., 2018). The arabinogalactan proteins (AGPs) and extensins are two members of the hydroxyprolinerich protein family. Both strengthen the cell wall through crosslinking with other cell wall components and participate in signal transduction (Pilling and Höfte, 2003; Deepak et al., 2010; Ringli, 2010; Seifert and Blaukopf, 2010). AGPs have effects on cell expansion, growth, and pattern formation. The consensus structure of AGPs comprises a large carbohydrate moiety of type II arabinogalactans $(\beta-(1,3)$-galactan backbone decorated with arabinose and other polysaccharides in side chains) O-linked to the hydroxyproline (Hyp) residues of the polypeptide backbone (repetitive AlaHyp, SerHyp, and ThrHyp peptides) with an $\mathrm{N}$-terminal signal sequence for secretion and a C-terminal glycosylphosphatidylinositol (GPI) lipid anchor tethering AGPs to the plasma membrane (Figure 2) (Knoch et al., 2014; Lamport et al., 2014; Tan et al., 2018). AGPs form a diverse class of proteins due to variable compositions of the peptide backbone and the carbohydrate moieties. Moore et al. (2006; 2013) supported the notion that AGPs serve as "plasticizers" to maintain cell wall flexibility during desiccation in the resurrection species Mohria caffrorum, $M$. flabellifolia, C. plantagineum, the grass-like Xerophyta spp., and the grass Erograstis nindensis. OGAs released from AGPs may facilitate to maintain intracellular osmotic pressure during dehydration according to the analysis of AGP genes in rice ( $\mathrm{Ma}$ and Zhao, 2010). However, the function of AGPs is probably not only restricted to the release of OGAs as signaling molecules, but AGPs may act as sensors (Ringli, 2010; Seifert and Blaukopf, 2010; Lamport et al., 2014; Novaković et al., 2018).

Extensins are characterized by the repetitive SerHyp 4 and SerHyp2 motif and the Tyr-Lys-Tyr sequence with Ser residues decorated with single galactose and minor arabinogalactan moieties attached to hydroxyproline residues (Shivaraj et al., 2018; Tan et al., 2018). The self-assembling extensins usually function as positively charged scaffolds, interacting with demethylesterified pectin via adsorption (Cannon et al., 2008; Valentin et al., 2010). Extensins facilitate the crosslinking of rhamnogalacturonan-II via borate and also contribute to ion- 
regulated cell wall integrity (Chormova and Fry, 2016; Tan et al., 2018). Besides a structural role, the proline-rich extensin-like receptor kinases have an effect on cell wall signal transduction. The T-DNA mutant perk4 (defective extensin-like receptor kinase) displayed decreased sensitivity to ABA and lower $\left[\mathrm{Ca}^{2+}\right]_{\text {cyt }}$ and $\mathrm{Ca}^{2+}$ channel currents upon ABA treatment (Bai et al., 2009). This supports a role of an extensin-like receptor kinase in $\mathrm{ABA}$ signaling and $\mathrm{Ca}^{2+}$ homeostasis.

\section{Cell Wall Modifying Proteins}

The remodeling of the polysaccharide composition under dehydration or rehydration is catalyzed by different cell wall modifying proteins and enzymes. Understanding the activity and regulation of these proteins and enzymes is crucial to decipher the folding process. Cell wall modifying enzymes are a group of cell wall proteins regulating cell wall composition and rheology. Here, three members of cell wall modifying proteins and their functions in resurrection plants are described.

\section{Expansins}

Expansins are hypothesized to prompt acid-induced growth and cell wall remodeling under abiotic stress by disrupting hydrogenbonds between xyloglucan and cellulose microfibrils without lytic activity (Figure 2) (Cosgrove, 2015; Tenhaken, 2015). Plant expansins fall into two major families: $\alpha$-expansins and $\beta$-expansins according to phylogenetic analyses (Cosgrove, 2015). The expression and activity of $\alpha$-expansins were studied in C. plantagineum leaves (Jones and McQueen-Mason, 2004). Among the three expansin transcripts the CplExp1 transcript level was correlated with expansin activity which increased in the early stages of dehydration and rehydration corresponding to cell wall extensibility (Jones and McQueen-Mason, 2004). This suggests a role of expansin-induced wall extension in the early stages of dehydration and rehydration. However, dehydration tends to alkalize the apoplast which leads to the question how the activity of acid-activated expansins can be triggered upon dehydration (Geilfus, 2017).

\section{Xyloglucan Endotransglucosylases/ Hydrolases}

Apart from expansins, the xyloglucan endotransglucosylases/ hydrolases (XTHs) are other candidates for unzipping the hemicellulose (xyloglucan)-cellulose network via hydrolysis or transglucosylation to increase the cell wall extensibility (Figure 2) (Sasidharan et al., 2011; Tenhaken, 2015). In contrast to expansins, XTHs exhibit two activities: irreversible xyloglucan hydrolysis (XEH) and reversible xyloglucan endotransglucosylation (XET), suggesting roles for XTHs in cell wall loosening and re-assembling (Rose et al., 2002). Transgenic A. thaliana and tomato plants overexpressing a xyloglucan endotransglucosylase/hydrolase $\mathrm{CaXTH} 3$ from hot pepper showed enhanced tolerance to salt and dehydration stress (Cho et al., 2006; Choi et al., 2011). In the resurrection plant, Haberlea rhodopensis, one putative XTH gene HrhDR35 was upregulated during early dehydration to desiccation and rehydration (Georgieva et al., 2012), which corresponds to expansin expression in C. plantagineum (Jones and McQueenMason, 2004). Based on these observations it is suggested that XTHs contribute to improve dehydration tolerance through increasing wall extensibility and cell wall reconstruction after stress relief in both desiccation tolerant and desiccation sensitive plants. However, XTHs may not always contribute to cell wall extensibility as was shown for cell walls of ripening tomato fruit (Saladié et al., 2006)

\section{Pectinmethylesterases}

The degree of pectin methylesterification is an important factor for cell wall structure and has an effect on cellular growth and cell wall responses during dehydration (Wolf et al., 2009). Pectinmethylesterases de-methylesterify pectin and thus generate negatively charged pectin (Figure 2). This reaction is affected by the apoplastic $\mathrm{pH}$ and the degree of methylesterification of galacturonic acid (Micheli, 2001; Wolf et al., 2012). The released pectin transfers $\mathrm{Ca}^{2+}$ to promote the formation of egg-box pectin gelatin which enhances the mechanical stability (Wolf et al., 2012; Voxeur and Höfte, 2016). Under dehydration the cell wall texture is presumably modified by the egg-box gelatin through activating pectinmethylesterases and inhibiting expansins due to the increased $\mathrm{pH}$ of the apoplast (Figure 2) (Wolf et al., 2012). Upon dehydration de-methylesterified pectin increases in the cell wall of C. wilmsii, C. plantagineum, and L. brevidens which is probably due to pectinmethylesterase activities during dehydration (Vicré et al., 1999; Vicré et al., 2004a; Jung et al., 2019).

The above-described cell wall proteins are not sufficient to explain the cell wall behavior during dehydration/rehydration in resurrection plants. Analyses of genome sequences have identified several other cell wall proteins in resurrection plants (Giarola et al., 2015). Giarola et al. (2015; 2016) identified a cysteine-rich protein localized in the apoplast and down-regulated during dehydration but up-regulated during rehydration, while the expression level of the CpGRP1 protein was enhanced during desiccation, which is consistent with the dehydration-induced GRP1 from Boea hygrometrica (Wang et al., 2009). Also aquaporins and plasma membrane intrinsic proteins accumulated upon dehydration or in the presence of $\mathrm{ABA}$ in $C$. plantagineum, suggesting that water channels are associated with ABA signaling during dehydration (Mariaux et al., 1998).

\section{CHANGES IN CELL WALL TRANSCRIPTOMES UPON DEHYDRATION IN RESURRECTION PLANTS}

In the past 10 years transcriptome-wide changes upon dehydration and rehydration have been reported for the dicot resurrection species C. plantagineum (Rodriguez et al., 2010), H. rhodopensis (Gechev et al., 2013), M. flabellifolia (Ma et al., 2015), and Boea hygrometrica (Xiao et al., 2015; Zhu et al., 2015), and for the monocot resurrection species Oropetium thomaeum (VanBuren et al., 2015) and Sporobolus stapfianus (Yobi et al., 2017). This 
information can be used to identify genes which are related to cell wall compartments. This will allow a comprehensive study of the molecular mechanisms which are activated to adapt the cell walls to the reducing cell volume caused by water loss in resurrection plants.

The analysis of transcriptome data showed that several cell wall-related genes which are involved in different processes such as the regulation of cell wall plasticity and cell wall dynamics, catabolic processes, and cell wall organization are differentially modulated upon dehydration thus suggesting the importance of cell wall remodeling during the acquisition of desiccation tolerance (Rodriguez et al., 2010; Gechev et al., 2013; Xiao et al., 2015; Zhu et al., 2015). One main obstacle to the interpretation of RNA expression data resides in the fact that genes encoding cell wall modifying enzymes belong to large gene families and often different enzyme isoforms in these families are differently regulated upon dehydration. Table 1 summarizes dehydration-induced changes in the expression of genes encoding cell wall modifying proteins and enzymes which were reported for resurrection species. A good example of enzyme isoforms which display an opposite expression upon dehydration is represented by xyloglucan endotransglucosylases (XTHs) in $H$. rhodopensis. Transcriptome data showed that several XTHs isoforms are down-regulated during dehydration (Gechev et al., 2013) (Table 1) but the presence of a dehydrationinduced XTH was previously identified by cDNA-AFLP experiments (Georgieva et al., 2012). Genes encoding XTHs, expansins, pectinmethylesterases, and pectinacetylesterases are

TABLE 1 | Dehydration-induced expression changes of cell wall enzymes which were reported for resurrection species.

\begin{tabular}{|c|c|c|c|}
\hline Species & Cell wall enzymes & Expression & Reference \\
\hline $\begin{array}{l}\text { Craterostigma } \\
\text { plantagineum }\end{array}$ & $\begin{array}{l}\text { Xyloglucan } \\
\text { endotransglucosylases, } \\
\text { pectin methylesterases } \\
\text { and pectin } \\
\text { acetylesterases }\end{array}$ & $\begin{array}{l}\text { Downregulated } \\
\text { upon dehydration }\end{array}$ & $\begin{array}{l}\text { (Rodriguez et al., } \\
\text { 2010) }\end{array}$ \\
\hline $\begin{array}{l}\text { Sporobolus } \\
\text { stapfianus }\end{array}$ & $\begin{array}{l}\text { Endo-beta-mannanase, } \\
\text { beta- mannan } \\
\text { endohydrolase, beta-D- } \\
\text { glucan exohydrolase, } \\
\text { glucan endo-1,3-beta- } \\
\text { glucosidase, feruloyl } \\
\text { esterase, glycosyl- } \\
\text { transferases }\end{array}$ & $\begin{array}{l}\text { very abundant in } \\
\text { late dehydration/ } \\
\text { desiccation (RWC } \\
\leq 30 \% \text { ) }\end{array}$ & (Yobi et al., 2017) \\
\hline $\begin{array}{l}\text { Sporobolus } \\
\text { stapfianus }\end{array}$ & $\begin{array}{l}\text { Cell wall-associated } \\
\text { hydrolases }\end{array}$ & $\begin{array}{l}\text { abundant in early } \\
\text { stage of } \\
\text { dehydration }(80 \% \\
\text { RWC) }\end{array}$ & (Yobi et al., 2017) \\
\hline $\begin{array}{l}\text { Sporobolus } \\
\text { stapfianus }\end{array}$ & $\begin{array}{l}\text { Cellulose synthases, } \\
\text { lichenase, glucan endo- } \\
\text { 1,3-beta-glucosidase, } \\
\text { anthocyanidin 5,3-O- } \\
\text { glucosyltransferase }\end{array}$ & $\begin{array}{l}\text { Downregulated } \\
\text { upon dehydration }\end{array}$ & (Yobi et al., 2017) \\
\hline $\begin{array}{l}\text { Haberlea } \\
\text { rhodopensis }\end{array}$ & $\begin{array}{l}\text { Xyloglucan } \\
\text { endotransglucosylases, } \\
\text { pectin esterases and } \\
\text { pectate lyases }\end{array}$ & $\begin{array}{l}\text { Downregulated } \\
\text { upon dehydration }\end{array}$ & $\begin{array}{l}\text { (Gechev et al., } \\
\text { 2013) }\end{array}$ \\
\hline $\begin{array}{l}\text { Haberlea } \\
\text { rhodopensis }\end{array}$ & Laccase & $\begin{array}{l}\text { Accumulated in } \\
\text { late dehydration/ } \\
\text { desiccation }\end{array}$ & $\begin{array}{l}\text { (Gechev et al., } \\
\text { 2013) }\end{array}$ \\
\hline
\end{tabular}

abundant in hydrated leaves of $C$. plantagineum and downregulated upon dehydration (Rodriguez et al., 2010). The stage where the maximum transcript expression is registered can also be hardly used as indicator for protein activity as this can be affected by additional factors, e.g., the binding with specific inhibitors, changes in the apoplastic $\mathrm{pH}$, the substrate accessibility, and/or the accumulation of ROS upon dehydration.

Our knowledge of structural changes in cell walls of dehydration sensitive species upon dehydration stress is limited and thus it is difficult to identify which mechanisms are specific for cell wall folding in resurrection species. Increased cell wall extensibility is observed upon dehydration in the resurrection species Craterostigma and it appears to be essential for cell wall folding and survival (Jones and McQueen-Mason, 2004). Conversely, sensitive plants subjected to drought stress tend to increase the stiffness of their cell walls (Lu and Neumann, 1998; Tenhaken, 2015). Expansins and XTHs have been proposed to be good candidates to increase cell wall extensibility in resurrection species. Additionally, other cell wall modifying proteins or enzymes, e.g., pectinmethylesterases are emerging as possible modulators of cell wall stiffness by acting on the methylesterification level of pectin. Finally, transcriptome data suggest the involvement of several classes of cell wall modifying enzymes and cell wall modifying enzyme inhibitors but the sole transcript data are far from providing a clear picture of how the different classes of cell wall proteins from these species are recruited and coordinated to achieve cell folding in resurrection species.

\section{CONCLUSIONS}

Cell wall remodeling is a pivotal drought tolerance mechanism for plants (Tenhaken, 2015), which includes two opposite effects: stiffening and loosening. Both effects contribute to the ability to overcome mechanical stress, while stiffening preferentially occurs in desiccation sensitive plants and loosening is essential for cell wall folding in resurrection plants. Maintaining the integrity of cell walls during dehydration and rehydration in resurrection plants involves many components ranging from changes in polysaccharide composition to differential RNA expression. The activation of pathways leading to more flexible components on the one hand and adding more stability to the cell wall on the other hand, suggests a tightly controlled folding process during dehydration which finally keeps the plasmalemma and the photosynthetic apparatus intact in resurrection plants.

\section{AUTHOR CONTRIBUTIONS}

PC, NJ, and VG wrote the manuscript. DB and VG supervised the work and corrected the manuscript.

\section{FUNDING}

PC acknowledges a fellowship from CSC and part of the work was supported by the DFG project Smartwall (BA 712-18-1). 


\section{REFERENCES}

Alpert, P. (2000). The discovery, scope, and puzzle of desiccation tolerance in plants. Plant Ecol. 151 (1), 5-17.doi: 10.1023/A:1026513800380

Bai, L., Zhang, G., Zhou, Y., Zhang, Z., Wang, W., Du, Y., et al. (2009). Plasma membrane-associated proline-rich extension-like receptor kinase 4, a novel regulator of $\mathrm{Ca}^{2+}$ signalling, is required for abscisic acid responses in Arabidopsis thaliana. Plant J. 60 (2), 314-327. doi: 10.1111/j.1365313X.2009.03956.X

Bartels, D., and Salamini, F. (2001). Desiccation tolerance in the resurrection plant Craterostigma plantagineum. A contribution to the study of drought tolerance at the molecular level. Plant Physiol. 127 (4), 1346-1353. doi: 10.1104/ pp. 010765

Basu, D., and Haswell, E. S. (2017). Plant mechanosensitive ion channels: an ocean of possibilities. Curr. Opin. Plant Biol. 40, 43-48. doi: 10.1016/j.pbi.2017.07.002

Baxter, A., Mittler, R., and Suzuki, N. (2014). ROS as key players in plant stress signalling. J. Exp. Bot. 65 (5), 1229-1240. doi: 10.1093/jxb/ert375

Bewley, J. D. (1979). Physiological aspects of desiccation tolerance. Annu. Rev. Plant Phys. 30, 195-238. doi: 10.1146/annurev.pp.30.060179.001211

Bidhendi, A. J., and Geitmann, A. (2016). Relating the mechanics of the primary plant cell wall to morphogenesis. J. Exp. Bot. 67 (2), 449-461. doi: 10.1093/jxb/ erv535

Boisson-Dernier, A., Lituiev, D. S., Nestorova, A., Franck, C. M., Thirugnanarajah, S., and Grossniklaus, U. (2013). ANXUR receptor-like kinases coordinate cell wall integrity with growth at the pollen tube tip via NADPH oxidases. PloS Biol. 11, e1001719. doi: 10.1371/journal.pbio.1001719

Bose, J., Pottosin, I., Shabala, S. S. S., Palmgren, M. G., and Shabala, S. (2011). Calcium efflux systems in stress signaling and adaptation in plants. Front. Plant Sci. 2, 85. doi: 10.3389/fpls.2011.00085

Bray, E. A. (1997). Plant responses to water deficit. Trends Plant Sci. 2, 48-54. doi: 10.1016/S1360-1385(97)82562-9

Cabrera, J. C., Boland, A., Messiaen, J., Cambier, P., and Van Cutsem, P. (2008). Egg box conformation of oligogalacturonides: The time-dependent stabilization of the elicitor-active conformation increases its biological activity. Glycobiology 18 (6), 473-482. doi: 10.1093/glycob/cwn027

Cabrera, J. C., Boland, A., Cambier, P., Frettinger, P., and Van Cutsem, P. (2010). Chitosan oligosaccharides modulate the supramolecular conformation and the biological activity of oligogalacturonides in Arabidopsis. Glycobiology 20 (6), 775-786. doi: $10.1093 / \mathrm{glycob} / \mathrm{cwq} 034$

Caffall, K. H., and Mohnen, D. (2009). The structure, function, and biosynthesis of plant cell wall pectic polysaccharides. Carbohyd. Res. 344, 1879-1900. doi: 10.1016/j.carres.2009.05.021

Caffall, K. H., Pattathil, S., Phillips, S. E., Hahn, M. G., and Mohnen, D. (2009). Arabidopsis thaliana T-DNA mutants implicate GAUT genes in the biosynthesis of pectin and xylan in cell walls and seed testa. Mol. Plant 2 (5), 1000-1014. doi: $10.1093 / \mathrm{mp} / \mathrm{ssp} 062$

Cannon, M. C., Terneus, K., Hall, Q., Tan, L., Wang, Y., Wegenhart, B. L., et al. (2008). Self-assembly of the plant cell wall requires an extensin scaffold. Proc. Natl. Acad. Sci. U.S.A. 105 (6), 2226-2231. doi: 10.1073/pnas.0711980105

Challabathula, D., and Bartels, D. (2013). Desiccation tolerance in resurrection plants: new insights from transcriptome, proteome and metabolome analysis. Front. Plant Sci. 4, 482. doi: 10.3389/fpls.201300482

Cheung, A. Y., and Wu, H. M. (2011). THESEUS 1, FERONIA and relatives: a family of cell wall-sensing receptor kinases? Curr. Opin. Plant Biol. 14 (6), 632641. doi: 10.1016/j.pbi.2011.09.001

Cho, S. K., Kim, J. E., Park, J.-A., Eom, T. J., and Kim, W. T. (2006). Constitutive expression of abiotic stress-inducible hot pepper CaXTH3, which encodes a xyloglucan endotransglucosylase/hydrolase homolog, improves drought and salt tolerance in transgenic Arabidopsis plants. FEBS Lett. 580 (13), 3136-3144. doi: 10.1016/j.febslet.2006.04.062

Choi, J. Y., Seo, Y. S., Kim, S. J., Kim, W. T., and Shin, J. S. (2011). Constitutive expression of CaXTH3, a hot pepper xyloglucan endotransglucosylase/ hydrolase, enhanced tolerance to salt and drought stresses without phenotypic defects in tomato plants (Solanum lycopersicum cv. Dotaerang). Plant Cell Rep. 30 (5), 867-877. doi: 10.1007/s00299-011-1032-z

Choi, W. G., Miller, G., Wallace, I., Harper, J., Mittler, R., and Gilroy, S. (2017). Orchestrating rapid long-distance signaling in plants with $\mathrm{Ca}^{2+}$, ROS and electrical signals. Plant J. 90 (4), 698-707. doi: 10.1111/tpj.13492
Chormova, D., and Fry, S. C. (2016). Boron bridging of rhamnogalacturonan-II is promoted in vitro by cationic chaperones, including polyhistidine and wall glycoproteins. New Phytol. 209 (1), 241-251. doi: 10.1111/nph.13596

Choudhury, F. K., Rivero, R. M., Blumwald, E., and Mittler, R. (2017). Reactive oxygen species, abiotic stress and stress combination. Plant J. 90 (5), 856-867. doi: $10.1111 /$ tpj.13299

Cleland, R. (1971). Cell wall extension. Annu. Rev. Plant Physiol. 22 (1), 197-222. doi: 10.1146/annurev.pp.22.060171.001213

Cosgrove, D. J. (2015). Plant expansins: diversity and interactions with plant cell walls. Curr. Opin. Plant Biol. 25, 162-172. doi: 10.1016/j.pbi.2015.05.014

Cosgrove, D. J. (2016). Plant cell wall extensibility: connecting plant cell growth with cell wall structure, mechanics, and the action of wall-modifying enzymes. J. Exp. Bot. 67 (2), 463-476. doi: 10.1093/jxb/erv511

De Lorenzo, G., Ferrari, S., Cervone, F., and Okun, E. (2018). Extracellular DAMPs in plants and mammals: Immunity, tissue damage and repair. Trends Immunol. 39 (11), 937-950. doi: 10.1016/j.it.2018.09.006

De Storme, N., and Geelen, D. (2014). Callose homeostasis at plasmodesmata: molecular regulators and developmental relevance. Front. Plant Sci. 5, 138. doi: $10.3389 /$ fpls.2014.00138

Decreux, A., and Messiaen, J. (2005). Wall-associated kinase WAK1 interacts with cell wall pectins in a calcium-induced conformation. Plant Cell Physiol. 46 (2), 268-278. doi: 10.1093/pcp/pci026

Deeba, F., Pandey, A. K., and Pandey, V. (2016). Organ specific proteomic dissection of Selaginella bryopteris undergoing dehydration and rehydration. Front. Plant Sci. 7, 425. doi: 10.3389/fpls.2016.00425

Deepak, S., Shailasree, S., Kini, R. K., Muck, A., Mithöfer, A., and Shetty, S. H. (2010). Hydroxyproline-rich glycoproteins and plant defence. J. Phytopathol. 158 (9), 585-593. doi: 10.1111/j.1439-0434.2010.01669.x

Denness, L., McKenna, J. F., Segonzac, C., Wormit, A., Madhou, P., Bennett, M., et al. (2011). Cell wall damage-induced lignin biosynthesis is regulated by a reactive oxygen species-and jasmonic acid-dependent process in. Arabidopsis. Plant Physiol. 156 (3), 1364-1374. doi: 10.1104/pp.111.175737

Dynowski, M., Schaaf, G., Loque, D., Moran, O., and Ludewig, U. (2008). Plant plasma membrane water channels conduct the signalling molecule $\mathrm{H}_{2} \mathrm{O}_{2}$. Biochem. J. 414, 53-61. doi: 10.1042/Bj20080287

Farrant, J. M., and Sherwin, H. W. (1998). "Mechanisms of desiccation tolerance in seeds and resurrection plants," in Progress in seed science research (Geneva, New York: Communication Services of the New York State Agricultural Experimental Station), 109-120.

Farrant, J. M., Brandt, W. B., and Lindsey, G. G. (2007). An overview of mechanisms of desiccation tolerance in selected angiosperm resurrection plants. Plant Stress 1 (1), 72-84. doi: 10.1002/9780470376881.ch3

Farrant, J. M. (2000). A comparison of mechanisms of desiccation tolerance among three angiosperm resurrection plant species. Plant Ecol. 151 (1), 29-39. doi: $10.1111 / j .1469-8137.2010 .03595 . x$

Feng, W., Kita, D., Peaucelle, A., Cartwright, H. N., Doan, V., Duan, Q., et al. (2018). The FERONIA receptor kinase maintains cell-wall integrity during salt stress through $\mathrm{Ca}^{2+}$ Signaling. Curr. Biol. 28 (5), 666-675. doi: 10.1016/ j.cub.2018.01.023

Fry, S. C., McDougall, G. J., Lorences, E. P., Biggs, K. J., and Smith, R. C. (1990). Oligosaccharins from xyloglucan and cellulose: modulators of the action of auxin and $\mathrm{H}^{+}$on plant growth. Symp. Soc Exp. Biol. 44, 285-298.

Fry, S. C. (1989). The structure and functions of xyloglucan. J. Exp. Bot. 40 (210), 1-11. doi: $10.1093 / \mathrm{Jxb} / 40.1 .1$

Fry, S. C. (1998). Oxidative scission of plant cell wall polysaccharides by ascorbateinduced hydroxyl radicals. Biochem. J. 332 (Pt 2), 507-515. doi: 10.1042/ bj3320507

Gaff, D. F. (1971). Desiccation-tolerant flowering plants in southern Africa. Science 174 (4013), 1033-1034. doi: 10.1126/science.174.40131033

Gechev, T. S., Benina, M., Obata, T., Tohge, T., Sujeeth, N., Minkov, I., et al. (2013). Molecular mechanisms of desiccation tolerance in the resurrection glacial relic Haberlea rhodopensis. Cell. Mol. Life Sci. 70 (4), 689-709. doi: 10.1007/s00018-012-1155-6

Geilfus, C. M. (2017). The $\mathrm{pH}$ of the apoplast: dynamic factor with functional impact under stress. Mol. Plant 10 (11), 1371-1386. doi: 10.1016/ j.molp.2017.09.018

Georgieva, T., Christov, N. K., and Djilianov, D. (2012). Identification of desiccation-regulated genes by cDNA-AFLP in Haberlea rhodopensis: a 
resurrection plant. Acta Physiol. Plant 34 (3), 1055-1066. doi: 10.1007/s11738011-0902-x

Giarola, V., Krey, S., Frerichs, A., and Bartels, D. (2015). Taxonomically restricted genes of Craterostigma plantagineum are modulated in their expression during dehydration and rehydration. Planta 241 (1), 193-208. doi: 10.1007/s00425014-2175-2

Giarola, V., Krey, S., von den Driesch, B., and Bartels, D. (2016). The Craterostigma plantagineum glycine-rich protein CpGRP1 interacts with a cell wall-associated protein kinase 1 (CpWAK1) and accumulates in leaf cell walls during dehydration. New Phytol. 210 (2), 535-550. doi: 10.1111/ nph.13766

Grant, G. T., Morris, E. R., Rees, D. A., Smith, P. J. C., and Thom, D. (1973). Biological Interactions between polysaccharides and divalent cations - egg-box model. FEBS Lett. 32 (1), 195-198. doi: 10.1016/0014-5793(73)80770-7

Hématy, K., Sado, P.-E., Van Tuinen, A., Rochange, S., Desnos, T., Balzergue, S., et al. (2007). A receptor-like kinase mediates the response of Arabidopsis cells to the inhibition of cellulose synthesis. Curr. Biol. 17 (11), 922-931. doi: 10.1016/j.cub.2007.05.018

Hamann, T., Bennett, M., Mansfield, J., and Somerville, C. (2009). Identification of cell-wall stress as a hexose-dependent and osmosensitive regulator of plant responses. Plant J. 57 (6), 1015-1026. doi: 10.1111/j.1365-313X.2008.03744.x

Hamann, T. (2014). The plant cell wall integrity maintenance mechanismConcepts for organization and mode of action. Plant Cell Physiol. 56 (2), 215-223. doi: 10.1093/pcp/pcul64

Hamilton, E. S., Schlegel, A. M., and Haswell, E. S. (2015). United in diversity: mechanosensitive ion channels in plants. Annu. Rev. Plant Biol. 66, 113-137. doi: 10.1146/annurev-arplant-043014-114700

Harholt, J., Suttangkakul, A., and Scheller, H. V. (2010). Biosynthesis of pectin. Plant Physiol. 153 (2), 384-395. doi: 10.1104/pp.110.156588

Herburger, K., Xin, A. Z., and Holzinger, A. (2019). Homogalacturonan accumulation in cell walls of the green alga Zygnema sp. (Charophyta) increases desiccation resistance. Front. Plant Sci. 10, 540. doi: 10.3389/ Fpls.2019.00540

Ingle, R. A., Schmidt, U. G., Farrant, J. M., Thomson, J. A., and Mundree, S. G. (2007). Proteomic analysis of leaf proteins during dehydration of the resurrection plant Xerophyta viscosa. Plant Cell Environ. 30 (4), 435-446. doi: $10.1111 / j .1365-3040.2006 .01631 . x$

Jarvis, M. C. (1984). Structure and properties of pectin gels in plant-cell walls. Plant Cell Environ. 7 (3), 153-164. doi: 10.1111/1365-3040.Ep11614586

Jones, L., and McQueen-Mason, S. (2004). A role for expansins in dehydration and rehydration of the resurrection plant Craterostigma plantagineum. FEBS Lett. 559 (1-3), 61-65. doi: 10.1016/S0014-5793(04)00023-7

Jovanović, Ž., Rakić, T., Stevanović, B., and Radović, S. (2011). Characterization of oxidative and antioxidative events during dehydration and rehydration of resurrection plant Ramonda nathaliae. Plant Growth Regul. 64 (3), 231-240. doi: 10.1007/s10725-011-9563-4

Jung, N. U., Giarola, V., Chen, P., Paul Knox, J., and Bartels, D. (2019). Craterostigma plantagineum cell wall composition is remodelled during desiccation and the glycine-rich protein CpGRP 1 interacts with pectins through clustered arginines. Plant J. 100, 661-676. doi: 10.1111/tpj.14479

Junttila, S., Laiho, A., Gyenesei, A., and Rudd, S. (2013). Whole transcriptome characterization of the effects of dehydration and rehydration on Cladonia rangiferina, the grey reindeer lichen. BMC Genomics 14 (1), 870. doi: 10.1186/ 1471-2164-14-870

Kangasjärvi, S., and Kangasjärvi, J. (2014). Towards understanding extracellular ROS sensory and signaling systems in plants. Adv. Bot. 2014, 538946. doi: $10.1155 / 2014 / 538946$

Karuppanapandian, T., Geilfus, C. M., Muhling, K. H., Novak, O., and Gloser, V. (2017). Early changes of the $\mathrm{pH}$ of the apoplast are different in leaves, stem and roots of Vicia faba L. under declining water availability. Plant Sci. 255, 51-58. doi: 10.1016/j.plantsci.2016.11.010

Kimura, S., Waszczak, C., Hunter, K., and Wrzaczek, M. (2017). Bound by fate: The role of reactive oxygen species in receptor-like kinase signaling. Plant Cell 29 (4), 638-654. doi: 10.1105/tpc.16.00947

Knoch, E., Dilokpimol, A., and Geshi, N. (2014). Arabinogalactan proteins: focus on carbohydrate active enzymes. Front. Plant Sci. 5, 198. doi: 10.3389/ Fpls.2014.00198
Kobayashi, M., Matoh, T., and Azuma, J. (1996). Two chains of rhamnogalacturonan II are cross-linked by borate-diol ester bonds in higher plant cell walls. Plant Physiol. 110 (3), 1017-1020. doi: 10.1104/pp.110.31017

Kohorn, B. D., Kobayashi, M., Johansen, S., Riese, J., Huang, L. F., Koch, K., et al. (2006). An Arabidopsis cell wall-associated kinase required for invertase activity and cell growth. Plant J. 46 (2), 307-316. doi: 10.1111/j.1365313X.2006.02695.x

Krebs, M., Held, K., Binder, A., Hashimoto, K., Den Herder, G., Parniske, M., et al. (2012). FRET-based genetically encoded sensors allow high-resolution live cell imaging of $\mathrm{Ca}^{2+}$ dynamics. Plant J. 69 (1), 181-192. doi: 10.1111/j.1365313X.2011.04780.x

Kurusu, T., Kuchitsu, K., Nakano, M., Nakayama, Y., and Iida, H. (2013). Plant mechanosensing and $\mathrm{Ca}^{2+}$ transport. Trends Plant Sci. 18 (4), 227-233. doi: 10.1016/j.tplants.2012.12.002

Lamport, D. T., Varnai, P., and Seal, C. E. (2014). Back to the future with the AGP$\mathrm{Ca}^{2+}$ flux capacitor. Ann. Bot. 114 (6), 1069-1085. doi: 10.1093/aob/mcul61

Lampugnani, E. R., Khan, G. A., Somssich, M., and Persson, S. (2018). Building a plant cell wall at a glance. J. Cell Sci. 131 (2), jcs207373. doi: 10.1242/jcs.207373

Le Gall, H., Philippe, F., Domon, J. M., Gillet, F., Pelloux, J., and Rayon, C. (2015). Cell wall metabolism in response to abiotic stress. Plants (Basel) 4 (1), 112-166. doi: $10.3390 /$ plants 4010112

Levitt, J., and Levitt, J. (1987). Responses of plants to environmental stresses (Vol. 2) (New York: Academic Press).

Lewicki, P. P. (1998). Effect of pre-drying treatment, drying and rehydration on plant tissue properties: a review. Int. J. Food Prop. 1 (1), 1-22. doi: 10.1080/ 10942919809524561

Lindner, H., Müller, L. M., Boisson-Dernier, A., and Grossniklaus, U. (2012). CrRLK1L receptor-like kinases: not just another brick in the wall. Curr. Opin. Plant Biol. 15 (6), 659-669. doi: 10.1016/j.pbi.2012.07.003

Lloyd, C. W. (1991). Cytoskeletal basis of plant growth and form (London: Academic Press).

Lu, Z. J., and Neumann, P. M. (1998). Water-stressed maize, barley and rice seedlings show species diversity in mechanisms of leaf growth inhibition. $J$. Exp. Bot. 49 (329), 1945-1952. doi: 10.1093/jexbot/49.3291945

Ma, H., and Zhao, J. (2010). Genome-wide identification, classification, and expression analysis of the arabinogalactan protein gene family in rice (Oryza sativa L.). J. Exp. Bot. 61 (10), 2647-2668. doi: 10.1093/jxb/erq104

Ma, C., Wang, H., Macnish, A. J., Estrada-Melo, A. C., Lin, J., Chang, Y. H., et al. (2015). Transcriptomic analysis reveals numerous diverse protein kinases and transcription factors involved in desiccation tolerance in the resurrection plant Myrothamnus flabellifolia. Hortic. Res. 2, 15034. doi: 10.1038/Hortres.2015.34

Ma, X. F., Wang, W. M., Bittner, F., Schmidt, N., Berkey, R., Zhang, L. L., et al. (2016). Dual and opposing roles of xanthine dehydrogenase in defenseassociated reactive oxygen species metabolism in Arabidopsis. Plant Cell 28 (5), 1108-1126. doi: 10.1105/tpc.15.00880

Mak, M., Babla, M., Xu, S.-C., O'Carrigan, A., Liu, X.-H., Gong, Y.-M., et al. (2014). Leaf mesophyll $\mathrm{K}^{+}, \mathrm{H}^{+}$and $\mathrm{Ca}^{2+}$ fluxes are involved in drought-induced decrease in photosynthesis and stomatal closure in soybean. Environ. Exp. Bot. 98, 1-12. doi: 10.1016/j.envexpbot.2013.10.003

Makavitskaya, M., Svistunenko, D., Navaselsky, I., Hryvusevich, P., Mackievic, V., Rabadanova, C., et al. (2018). Novel roles of ascorbate in plants: induction of cytosolic $\mathrm{Ca}^{2+}$ signals and efflux from cells via anion channels. J. Exp. Bot. 69 (14), 3477-3489. doi: 10.1093/jxb/ery056

Mangano, S., Pacheco, J. M., Marino-Buslje, C., and Estevez, J. M. (2018). How does $\mathrm{pH}$ fit in with oscillating polar growth? Trends Plant Sci. 23 (6), 479-489. doi: 10.1016/j.tplants.2018.02.008

Mariaux, J. B., Bockel, C., Salamini, F., and Bartels, D. (1998). Desiccation- and abscisic acid-responsive genes encoding major intrinsic proteins (MIPs) from the resurrection plant Craterostigma plantagineum. Plant Mol. Biol. 38 (6), 1089-1099. doi: 10.1023/a:1006013130681

Medvedev, S. S. (2005). Calcium signaling system in plants. Russ. J. Plant Physiol. 52 (2), 249-270. doi: 10.1007/s11183-005-0038-1

Micheli, F. (2001). Pectin methylesterases: cell wall enzymes with important roles in plant physiology. Trends Plant Sci. 6 (9), 414-419. doi: 10.1016/S1360-1385 (01)02045-3

Mihailova, G., Kocheva, K., Goltsev, V., Kalaji, H. M., and Georgieva, K. (2018). Application of a diffusion model to measure ion leakage of resurrection plant 
leaves undergoing desiccation. Plant Physiol. Bioch. 125, 185-192. doi: 10.1016/ j.plaphy.2018.02.008

Miller, G., Suzuki, N., Ciftci-Yilmaz, S., and Mittler, R. (2010). Reactive oxygen species homeostasis and signalling during drought and salinity stresses. Plant Cell Environ. 33 (4), 453-467. doi: 10.1111/j.1365-3040.2009.02041.x

Mittler, R. (2017). ROS are good. Trends Plant Sci. 22 (1), 11-19. doi: 10.1016/ j.tplants.2016.08.002

Mohnen, D. (2008). Pectin structure and biosynthesis. Curr. Opin. Plant Biol. 11, 266-277. doi: 10.1016/j.pbi.2008.03.006

Moore, P. J., Darvill, A. G., Albersheim, P., and Staehelin, L. A. (1986). Immunogold localization of xyloglucan and rhamnogalacturonan-I in the cell-walls of suspension-cultured sycamore cells. Plant Physiol. 82 (3), 787794. doi: 10.1104/Pp.82.3.787

Moore, J. P., Nguema-Ona, E., Chevalier, L., Lindsey, G. G., Brandt, W. F., Lerouge, P., et al. (2006). Response of the leaf cell wall to desiccation in the resurrection plant Myrothamnus flabellifolius. Plant Physiol. 141 (2), 651-662. doi: 10.1104/pp.106.077701

Moore, J. P., Vicre-Gibouin, M., Farrant, J. M., and Driouich, A. (2008). Adaptations of higher plant cell walls to water loss: drought vs desiccation. Physiol. Plant 134 (2), 237-245. doi: 10.1111/j.1399-3054.2008.01134.x

Moore, J. P., Nguema-Ona, E. E., Vicre-Gibouin, M., Sorensen, I., Willats, W. G. T., Driouich, A., et al. (2013). Arabinose-rich polymers as an evolutionary strategy to plasticize resurrection plant cell walls against desiccation. Planta 237 (3), 739-754. doi: 10.1007/s00425-012-1785-9

Moscatiello, R., Mariani, P., Sanders, D., and Maathuis, F. J. M. (2006). Transcriptional analysis of calcium-dependent and calcium-independent signalling pathways induced by oligogalacturonides. J. Exp. Bot. 57 (11), 2847-2865. doi: 10.1093/jxb/erl043

Murphy, E., and De Smet, I. (2014). Understanding the RALF family: a tale of many species. Trends Plant Sci. 19 (10), 664-671. doi: 10.1016/j.tplants.2014.06.005

Nürnberger, T., and Kemmerling, B. (2018). Pathogen-associated molecular patterns (PAMP) and PAMP-triggered immunity. Ann. Plant Revi. Online, 34, 16-47. doi: 10.1002/9781119312994.apr0362

Nielsen, M. E., Feechan, A., Böhlenius, H., Ueda, T., and Thordal-Christensen, H. (2012). Arabidopsis ARF-GTP exchange factor, GNOM, mediates transport required for innate immunity and focal accumulation of syntaxin PEN1. Proc. Natl. Acad. Sci. U.S.A. 109 (28), 11443-11448. doi: 10.1073/pnas.1117596109

Nishiyama, Y. (2009). Structure and properties of the cellulose microfibril. J. Wood Sci. 55 (4), 241-249. doi: 10.1007/s10086-009-1029-1

Novaković, L., Guo, T., Bacic, A., Sampathkumar, A., and Johnson, K. (2018). Hitting the wall-sensing and signaling pathways involved in plant cell wall remodeling in response to abiotic stress. Plants 7 (4), 89. doi: 10.3390/plants7040089

O’Brien, J. A., Daudi, A., Finch, P., Butt, V. S., Whitelegge, J. P., Souda, P., et al. (2012). A peroxidase-dependent apoplastic oxidative burst in cultured Arabidopsis cells functions in MAMP-elicited defense. Plant Physiol. 158 (4), 2013-2027. doi: 10.1104/pp.111.190140

O’Neill, M. A., Eberhard, S., Albersheim, P., and Darvill, A. G. (2001). Requirement of borate cross-linking of cell wall rhamnogalacturonan II for Arabidopsis growth. Science 294, 846-849. doi: 10.1126/science.1062319

Osorio, S., Castillejo, C., Quesada, M. A., Medina-Escobar, N., Brownsey, G. J., Suau, R., et al. (2008). Partial demethylation of oligogalacturonides by pectin methyl esterase 1 is required for eliciting defence responses in wild strawberry (Fragaria vesca). Plant J. 54 (1), 43-55. doi: 10.1111/j.1365-313X.2007.03398.x

Park, Y. B., and Cosgrove, D. J. (2015). Xyloglucan and its interactions with other components of the growing cell wall. Plant Cell Physiol. 56 (2), 180-194. doi: $10.1093 / \mathrm{pcp} / \mathrm{pcu} 204$

Parre, E., and Geitmann, A. (2005). Pectin and the role of the physical properties of the cell wall in pollen tube growth of Solanum chacoense. Planta 220 (4), 582-592. doi: 10.1007/s00425-004-1368-5

Passardi, F., Penel, C., and Dunand, C. (2004). Performing the paradoxical: how plant peroxidases modify the cell wall. Trends Plant Sci. 9 (11), 534-540. doi: 10.1016/j.tplants.2004.09.002

Phillips, J. R., Fischer, E., Baron, M., Van Den Dries, N., Facchinelli, F., Kutzer, M., et al. (2008). Lindernia brevidens: a novel desiccation-tolerant vascular plant, endemic to ancient tropical rainforests. Plant J. 54 (5), 938-948. doi: 10.1111/ j.1365-313X.2008.03478.X

Pilling, E., and Höfte, H. (2003). Feedback from the wall. Curr. Opin. Plant Biol. 6 (6), 611-616. doi: 10.1016/j.pbi.2003.09.004
Plancot, B., Gügi, B., Mollet, J. C., Loutelier-Bourhis, C., Govind, S. R., Lerouge, P., et al. (2019). Desiccation tolerance in plants: Structural characterization of the cell wall hemicellulosic polysaccharides in three Selaginella species. Carbohyd. Polym. 208, 180-190. doi: 10.1016/j.carbpol.2018.12.051

Ramanjulu, S., and Bartels, D. (2002). Drought- and desiccation-induced modulation of gene expression in plants. Plant Cell Environ. 25 (2), 141151. doi: $10.1046 / j .0016-8025.2001 .00764 . x$

Ringli, C. (2010). Monitoring the outside: cell wall-sensing mechanisms. Plant Physiol. 153 (4), 1445-1452. doi: 10.1104/pp.110.154518

Rodriguez, M. C. S., Edsgärd, D., Hussain, S. S., Alquezar, D., Rasmussen, M., Gilbert, T., et al. (2010). Transcriptomes of the desiccation-tolerant resurrection plant Craterostigma plantagineum. Plant J. 63 (2), 212-228. doi: 10.1111/j.1365-313X.2010.04243.x

Rose, J. K., Braam, J., Fry, S. C., and Nishitani, K. (2002). The XTH family of enzymes involved in xyloglucan endotransglucosylation and endohydrolysis: current perspectives and a new unifying nomenclature. Plant Cell Physiol. 43 (12), 1421-1435. doi: 10.1093/pcp/pcf171

Ryden, P., Sugimoto-Shirasu, K., Smith, A. C., Findlay, K., Reiter, W. D., and McCann, M. C. (2003). Tensile properties of Arabidopsis cell walls depend on both a xyloglucan cross-linked microfibrillar network and rhamnogalacturonan II-borate complexes. Plant Physiol. 132 (2), 1033-1040. doi: $10.1104 /$ pp.103.021873

Saladié, M., Rose, J. K., Cosgrove, D. J., and Catalá, C. (2006). Characterization of a new xyloglucan endotransglucosylase/hydrolase (XTH) from ripening tomato fruit and implications for the diverse modes of enzymic action. Plant J. 47 (2), 282-295. doi: 10.1111/j.1365-313X.2006.02784.x

Sasidharan, R., Voesenek, L. A. C. J., and Pierik, R. (2011). Cell wall modifying proteins mediate plant acclimatization to biotic and abiotic stresses. Crit. Rev. Plant Sci. 30 (6), 548-562. doi: 10.1080/07352689.2011.615706

Seifert, G. J., and Blaukopf, C. (2010). Irritable Walls: The plant extracellular matrix and signaling. Plant Physiol. 153 (2), 467-478. doi: 10.1104/ pp. 110.153940

Sherwin, H. W., and Farrant, J. M. (1998). Protection mechanisms against excess light in the resurrection plants Craterostigma wilmsii and Xerophyta viscosa. Plant Growth Regul. 24 (3), 203-210. doi: 10.1023/A:1005801610891

Shivaraj, Y. N., Barbara, P., Gugi, B., Vicre-Gibo, M., Driouich, A., Govind, S. R., et al. (2018). Perspectives on structural, physiological, cellular, and molecular responses to desiccation in resurrection plants. Scientifica 2018, 18. doi: $10.1155 / 2018 / 9464592$

Simmons, T. J., Mortimer, J. C., Bernardinelli, O. D., Pöppler, A. C., Brown, S. P., Deazevedo, E. R., et al. (2016). Folding of xylan onto cellulose fibrils in plant cell walls revealed by solid-state NMR. Nat. Commun. 7, 13902. doi: 10.1038/ ncomms 13902

Spoel, S. H., and Loake, G. J. (2011). Redox-based protein modifications: the missing link in plant immune signalling. Curr. Opin. Plant Biol. 14, 358-364. doi: 10.1016/j.pbi.2011.03.007

Staehelin, L. A., and Moore, I. (1995). The plant Golgi apparatus: structure, functional organization and trafficking mechanisms. Annu. Rev. Plant Phys. 46 (1), 261-288. doi: 10.1146/annurev.pp.46.060195.001401

Sterling, J. D., Quigley, H. F., Orellana, A., and Mohnen, D. (2001). The catalytic site of the pectin biosynthetic enzyme $\alpha$-1, 4-galacturonosyltransferase is located in the lumen of the Golgi. Plant Physiol. 127 (1), 360-371. doi: 10.1104/pp.127.1.360

Suzuki, N., Miller, G., Morales, J., Shulaev, V., Torres, M. A., and Mittler, R. (2011). Respiratory burst oxidases: the engines of ROS signaling. Curr. Opin. Plant Biol. 14 (6), 691-699. doi: 10.1016/j.pbi.2011.07.014

Takeda, T., Furuta, Y., Awano, T., Mizuno, K., Mitsuishi, Y., and Hayashi, T. (2002). Suppression and acceleration of cell elongation by integration of xyloglucans in pea stem segments. Proc. Natl. Acad. Sci. U.S.A. 99 (13), 9055-9060. doi: 10.1073/pnas.132080299

Tan, L., Tees, D., Qian, J., Kareem, S., and Kieliszewski, M. J. (2018). Intermolecular interactions between glycomodules of plant cell wall arabinogalactan-proteins and extensins. Cell Surf. 1, 25-33. doi: 10.1016/j.tcsw.2018.03.001

Tardieu, F., Parent, B., Caldeira, C. F., and Welcker, C. (2014). Genetic and physiological controls of growth under water deficit. Plant Physiol. 164 (4), 1628-1635. doi: 10.1104/pp.113.233353

Tenhaken, R. (2015). Cell wall remodeling under abiotic stress. Front. Plant Sci. 5, 771. doi: 10.3389/Fpls.2014.00771 
Thomson, W. W., and Platt, K. A. (1997). Conservation of cell order in desiccated mesophyll of Selaginella lepidophylla ([Hook and Grev] Spring). Ann. BotLondon. 79, 439-447. doi: 10.1006/anbo.19960375

Valentin, R., Cerclier, C., Geneix, N., Aguie-Beghin, V., Gaillard, C., Ralet, M. C., et al. (2010). Elaboration of extensin-pectin thin film model of primary plant cell wall. Langmuir 26 (12), 9891-9898. doi: 10.1021/la100265d

VanBuren, R., Bryant, D., Edger, P. P., Tang, H. B., Burgess, D., Challabathula, D., et al. (2015). Single-molecule sequencing of the desiccation-tolerant grass Oropetium thomaeum. Nature 527 (7579), 508-U209. doi: 10.1038/nature15714

VanBuren, R., Wai, C. M., Zhang, Q., Song, X., Edger, P. P., Bryant, D., et al. (2017). Seed desiccation mechanisms co-opted for vegetative desiccation in the resurrection grass Oropetium thomaeum. Plant Cell Environ. 40 (10), 22922306. doi: $10.1111 /$ pce. 13027

Veley, K. M., Maksaev, G., Frick, E. M., January, E., Kloepper, S. C., and Haswell, E. S. (2014). Arabidopsis MSL10 has a regulated cell death signaling activity that is separable from its mechanosensitive ion channel activity. Plant Cell 26 (7), 3115-3131. doi: 10.1105/tpc.114.128082

Vicré, M., Sherwin, H. W., Driouich, A., Jaffer, M. A., and Farrant, J. M. (1999). Cell wall characteristics and structure of hydrated and dry leaves of the resurrection plant Craterostigma wilmsii, a microscopical study. J. Plant Physiol. 155 (6), 719-726. doi: 10.1016/S0176-1617(99)80088-1

Vicré, M., Farrant, J. M., and Driouich, A. (2004a). Insights into the cellular mechanisms of desiccation tolerance among angiosperm resurrection plant species. Plant Cell Environ. 27 (11), 1329-1340. doi: 10.1111/j.13653040.2004.01212.x

Vicré, M., Lerouxel, O., Farrant, J., Lerouge, P., and Driouich, A. (2004b). Composition and desiccation-induced alterations of the cell wall in the resurrection plant Craterostigma wilmsii. Physiol. Plant 120 (2), 229-239. doi: 10.1111/j.0031-9317.2004.0234.x

Voothuluru, P., and Sharp, R. E. (2013). Apoplastic hydrogen peroxide in the growth zone of the maize primary root under water stress. I. Increased levels are specific to the apical region of growth maintenance. J. Exp. Bot. 64 (5), 1223-1233. doi: $10.1093 / \mathrm{jxb} / \mathrm{ers} 277$

Voxeur, A., and Höfte, H. (2016). Cell wall integrity signaling in plants: "To grow or not to grow that's the question". Glycobiology 26 (9), 950-960. doi: 10.1093/ glycob/cww029

Wang, L., Shang, H., Liu, Y., Zheng, M., Wu, R., Phillips, J., et al. (2009). A role for a cell wall localized glycine-rich protein in dehydration and rehydration of the resurrection plant Boea hygrometrica. Plant Biol. 11 (6), 837-848. doi: 10.1111/ j.1438-8677.2008.00187.x

Wang, T., Zabotina, O., and Hong, M. (2012). Pectin-cellulose interactions in the Arabidopsis primary cell wall from two-dimensional magic-angle-spinning solid-state nuclear magnetic resonance. Biochemistry 51 (49), 9846-9856. doi: $10.1021 / \mathrm{bi} 3015532$

Webb, M. A., and Arnott, H. J. (1982). Cell-wall conformation in dry seeds in relation to the preservation of structural integrity during desiccation. Am. J. Bot. 69, 1657-1668. doi: 10.1002/j.1537-2197.1982.tb13418.x
Wolf, S., Mouille, G., and Pelloux, J. (2009). Homogalacturonan methylesterification and plant development. Mol. Plant 2 (5), 851-860. doi: $10.1093 / \mathrm{mp} / \mathrm{ssp} 066$

Wolf, S., Hematy, K., and Hofte, H. (2012). Growth control and cell wall signaling in plants. Annu. Rev. Plant Biol. 63, 381-407. doi: 10.1146/annurev-arplant042811-105449

Wrzaczek, M., Brosché, M., and Kangasjärvi, J. (2013). ROS signaling loopsproduction, perception, regulation. Curr. Opin. Plant Biol. 16 (5), 575-582. doi: 10.1016/j.pbi.2013.07.002

Xiao, L. H., Yang, G., Zhang, L. C., Yang, X. H., Zhao, S., Ji, Z. Z., et al. (2015). The resurrection genome of Boea hygrometrica: A blueprint for survival of dehydration. Proc. Natl. Acad. Sci. U.S.A. 112 (18), 5833-5837. doi: 10.1073/ pnas. 1505811112

Xu, Z., Xin, T., Bartels, D., Li, Y., Gu, W., Yao, H., et al. (2018). Genome analysis of the ancient tracheophyte Selaginella tamariscina reveals evolutionary features relevant to the acquisition of desiccation tolerance. Mol. Plant. 11 (7), 983-994. doi: 10.1016/j.molp.2018.05.00

Yobi, A., Schlauch, K. A., Tillett, R. L., Yim, W. C., Espinoza, C., Wone, B. W. M., et al. (2017). Sporobolus stapfianus: Insights into desiccation tolerance in the resurrection grasses from linking transcriptomics to metabolomics. BMC Plant Biol. 17 (1), 67. doi: 10.1186/s12870-017-1013-7

Zablackis, E., Huang, J., Muller, B., Darvill, A. G., and Albersheim, P. (1995). Characterization of the cell-wall polysaccharides of Arabidopsis thaliana leaves. Plant Physiol. 107 (4), 1129-1138. doi: 10.1104/pp.107.41129

Zhang, Q., and Bartels, D. (2018). Molecular responses to dehydration and desiccation in desiccation-tolerant angiosperm plants. J. Exp. Bot. 69 (13), 3211-3222. doi: 10.1093/jxb/erx489

Zhang, G. F., and Staehelin, L. A. (1992). Functional compartmentation of the Golgi apparatus of plant cells: immunocytochemical analysis of high-pressure frozen-and freeze-substituted sycamore maple suspension culture cells. Plant Physiol. 99 (3), 1070-1083. doi: 10.1104/pp.99.31070

Zhu, Y., Wang, B., Phillips, J., Zhang, Z. N., Du, H., Xu, T., et al. (2015). Global transcriptome analysis reveals acclimation-primed processes involved in the acquisition of desiccation tolerance in Boea hygrometrica. Plant Cell Physiol. 56 (7), 1429-1441. doi: 10.1093/pcp/pcv059

Conflict of Interest: The authors declare that the research was conducted in the absence of any commercial or financial relationships that could be construed as a potential conflict of interest.

Copyright $\odot 2020$ Chen, Jung, Giarola and Bartels. This is an open-access article distributed under the terms of the Creative Commons Attribution License (CC $B Y$ ). The use, distribution or reproduction in other forums is permitted, provided the original author(s) and the copyright owner(s) are credited and that the original publication in this journal is cited, in accordance with accepted academic practice. No use, distribution or reproduction is permitted which does not comply with these terms. 